球側にて着脱可能なコリメータを試作した。結果的には 患者被曝の減少とスライス厚方向の周波数特性の改善之 いう当然の結論を得ている。なお，発表の中でビーム幅 という表現があるがスライス厚とすべきむのであろう。

演題 253 は CT 装置のスライス厚を CT の Partial Volume 効果によって測定する Partial Volume 法につ いて発表した。自部門の有する CTスキャナだけでな く，他の病院の有する各メ一カのCT スキャナのスライ 又厚が本法によって測定されており興味深い内容であっ た. $2 \mathrm{~mm}$ スライス厚以下では公称値との差が10 30\% ああったと報告されており，考慮されるべきであろう。

演題254の発表は大変ユニークであった：線源に超 音 波を用いてい゙る点，X線 CT とは異なるが画像再構成， 表示系などの学習用としては安価によくできていると言 ってよいだろう。

演題255は現在市販されている商用のCT スキャナの X線管電圧が殆んど $120 \mathrm{kV}$ 固定である点にスポットを 当て， $80 \mathrm{kV}$ における CT 値の変化その他を調べた. 今 後とあ重要なテーマである.

演題 256 はプロシェクション数とCT の諸性能につい て言及した。 その結果は CT の原理とよく一致してい る.

以上，X線 CTははほぼ完成されたマシンと思われがち だが今後とあ地道な研究が続けられるべきだと考える。

\section{CT-3 ダイナミック}

座長 馬場 任 (九州大学)

257. ダイナミックスキャンの画質特性と臨床的応用

兵庫県立姫路循環器病センタ一

○中島義明・田中雅敏・小林一好 高橋龍児・估古正雄

1 スキャン $2 \sim 3$ 枚画像の機構を持つダイナミック CT の画質特性に関するファントム実験ではデータ不足によ るノイズの増加は避けられないが，高，低コントラスト 分解能，再現性，MTF 等に特に大きな低下は認められ ず問題はない。臨床では肝の血流特に門脈流の評価を time density curve より各症例別に $\mathrm{AH}$ ratio を算出し たが結果は明らかに有意の差を確認した。乙れより肝の 血流評洒のパラメータとしでの可能性が示唆され, embolization への適応を検討したい. 頭部では頚動脈閉塞

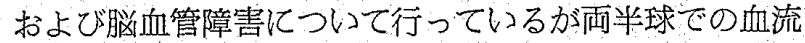
の時閔的ズレ, Angioで確認できない脳血流, 術後患者 のバイパス開在に対し特に有用であった.

258. CT Dynamic Study における造影剂注入法の検討
- Table Incremented Rapid Squence Scanning 国立盾環器病センンター放射線揨療部

○小食裕樹・佐久間利治 福西康修・内田英治

〔目的]CTによる動態検查が日常化してきた今日， 造影郕の急速大量注入监必要不可欠となりつつある。当 院においては，より良い造影効果と検查成績の再現性を 得るため, 造影剤自動注入器を使用し, 对象臓器, 疾患 により異なった造影剤の注入方法を考察した。

〔結論】造影剤の血中消失速度は意外亡速いため，短 時間に大量の造影剤を注入して血中造影㣂濃度を高度に し，それを長時間維持，連続ズキンを行なうととが必 要である：今回，造影剤自動注入器を使用するととによ り，造影効果加向上し，検查成績が安定した：合わせて 造影剂畫の娍少ができた。

259. カーディアックスキャン・システムの開発と臨床 応用について

独協医科大学病院放射線

○會前 茂・三代 忠・松村義光 東芝 CT 技術部

荒瀬正邦・井上順二・朝比奈清敬

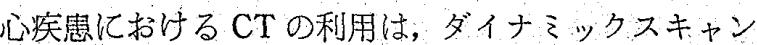
に加え，心電図 (ECG) と同期した画像データを収集し， 同期画像を得るシステムを備えた CT の出現により虚血 性心疾患等の臨床にルチンに使用されつつある。今回， 当院に拉いて東芝 CT 技術部乙の共同開発の機会を得た ので，そのシステムの概要と臨床応用について報告し た. 心軸に対する体軸の偏向が可能なテーブルの作製. ガントリー曰径の改良，造影剤の投与亿ついては，現時 点では, boulus rate injection ( $1 \sim 1.5 \mathrm{ml}$ 秒) $50 \mathrm{ml}$ を scan 前认注入. 絸けて sacn スタートと同時 rate injection (1〜1.5 ml/sec) $90 \mathrm{ml}$ を入れながら得たゲートイ メーシ力゙良好であった。電図表示，アニメーション画 像も可能となった。

260. CTを利用した心拍同期スキャン(ハートゲートス キャン）による心室容積の測定

慶応義塾大学病院 CT スキャン室

○鈴木 保・朝畣 崇・清水正三 島田泰富・渡部敏男・清水正勝

当院におして，CTによる心拍同期スキャンによる心 室容積の測定並びに動態観察も行ったので報告する。 ンプソン法を参考にし，患者を右側卧位にし，ガントリ を $15^{\circ}$ 頭側に傾ける事により，心臓の短軸に平行にスう イスできた。 上腕静脈まで插入したロングェラスター針 